\title{
Evaluasi Pelayanan Kefarmasian Di Puskesmas Kabupaten Ponorogo
}

\author{
Ika Norcahyanti ${ }^{1,2}$, Farda Hakimah ${ }^{1}$, Fransiska Maria Christianty ${ }^{1,2}$ \\ ${ }^{I}$ Department of Clinical and Community Pharmacy, Faculty of Pharmacy, Universitas Jember, East Java, Indonesia \\ ${ }^{2}$ Drug Utilization Research Group, Faculty of Pharmacy, Universitas Jember, East Java, Indonesia \\ *E-mail: norcahyanti.farmasi@unej.ac.id
}

\begin{abstract}
Public health center is a primary health facility, and pharmacy services support its activities. Periodic monitoring and evaluation of activities are needed to assure the quality of pharmaceutical services. Pharmacy personnels can evaluate pharmaceutical services at the public health center using a guideline published in 2008 by the Directorate of Pharmacy and Community Clinics of the Indonesian Ministry of Health. The purpose of this study was to determine the characteristics, description, and quality of pharmaceutical services at the public health centers in Ponorogo after being evaluated using a list of pharmaceutical services in 2008. This research was an observational survey on all pharmacy personnels and other personnels responsible for the pharmacy room at the public health center in Ponorogo. The analysis of data was using descriptive techniques. The results show that the public health centers were mostly an inpatient center (n=19; 61.3\%) and accredited 'madya' $(n=22 ; 71 \%)$. Morover, the head of a pharmacy room was dominantly a pharmacy technician $(n=24$; 77.4\%). Pharmaceutical services generally fulfilled the supporting for and quality control indicators. However, several indicators did not fully meet the guideline, including clinical judgements, counseling, and home care. Overall, only three public health centers can be rated "good" in delivering quality pharmaceutical services, whilst the other eight and twenty were rated "moderate" and "less", respectively.
\end{abstract}

Keywords: evaluation, public health center, pharmaceutical service

\section{Pendahuluan}

Peraturan Pemerintah RI Nomor 36 Tahun 2009 menyatakan bahwa ketersediaan fasilitas pelayanan kesehatan untuk meningkatkan derajat kesehatan masyarakat berada di bawah tanggung jawab pemerintah.[1] Jenis fasilitas pelayanan kesehatan salah satunya adalah pusat kesehatan masyarakat (Puskesmas) [2] yang berfungsi menyelenggarakan Upaya Kesehatan Masyarakat (UKM) dan Upaya Kesehatan Perseorangan (UKP) di wilayah kerjanya pada satu kecamatan. UKM dan UKP dalam pelaksanaannya harus ditunjang salah satunya oleh pelayanan kefarmasian. [4]

Pelayanan kefarmasian dalam realisasinya harus berpedoman pada Standar Pelayanan Kefarmasian yang diatur dalam Peraturan Menteri Kesehatan RI Nomor 74 Tahun 2016. Standar pelayanan kefarmasian di Puskesmas meliputi pengelolaan sediaan farmasi dan bahan medis habis pakai serta pelayanan farmasi klinik. Pada prosesnya, diperlukan monitoring dan evaluasi kegiatan secara berkala sebagai upaya untuk menjamin mutu pelayanan kefarmasian agar tetap berjalan baik.[3] Selain itu, kegiatan monitoring dan evaluasi juga bertujuan untuk memperoleh gambaran mutu pelayanan kefarmasian sebagai dasar perbaikan pelayanan kefarmasian Puskesmas di masa mendatang.[6]

Evaluasi pada pelayanan kefarmasian di Puskesmas dapat dilakukan berdasarkan pedoman yang telah dikeluarkan oleh Direktorat Bina Farmasi Komunitas dan Klinik Kementerian Kesehatan RI. Pedoman tersebut mencakup 7 pokok pembahasan antara lain: pelayanan kefarmasian, pengelolaan sumber daya, pelayanan resep, pelayanan informasi obat, prosedur tetap, administrasi, serta monitoring dan evaluasi. [7]

Berdasarkan data yang disampaikan oleh Dinas Kesehatan Kabupaten Ponorogo per Mei 2019 diketahui bahwa terdapat 31 Puskesmas yang tersebar di seluruh kecamatan. Penelitian ini bertujuan untuk mengevaluasi pelayanan kefarmasian di Puskesmas Kabupaten Ponorogo. Melalui penelitian ini diharapkan dapat mengetahui karakteristik dan gambaran pelayanan kefarmasian di Puskesmas Kabupaten Ponorogo serta mengetahui kualitas pelayanan kefarmasian di Puskesmas Kabupaten Ponorogo setelah dievaluasi menggunakan Pedoman Daftar Tilik Pelayanan Kefarmasian Tahun 2008. 


\section{Bahan dan Metode}

Penelitian ini merupakan penelitian observasional menggunakan metode survei. Penelitian dilakukan pada 31 Puskesmas Kabupaten Ponorogo pada bulan September hingga November 2019. Populasi dalam penelitian ini adalah seluruh tenaga kefarmasian atau tenaga lain yang bertanggung jawab terhadap ruang farmasi di Puskesmas Kabupaten Ponorogo, dimana sampel kemudian dipilih menggunakan teknik total sampling. Instrumen yang digunakan dalam penelitian ini adalah pedoman daftar tilik yang dikeluarkan oleh Direktorat Bina Farmasi Komunitas dan Klinik Kementerian Kesehatan RI Tahun 2008.

Pengumpulan data dilakukan dengan cara observasi dan wawancara kepada responden yang terlebih dahulu diberikan informasi untuk mengisi informed consent.

Data yang telah terkumpul kemudian dianalisis dengan cara menghitung total skor berdasarkan ketentuan berikut:
1. Skor untuk pernyataan "ya" adalah 2 dan "tidak" adalah 0 .

2. Skor untuk pelaksana pelayanan kefarmasian dilakukan oleh "apoteker" adalah 2, oleh "TTK" adalah 1, dan oleh "tenaga kesehatan lain" serta "tidak dilakukan" adalah 0.

Kualitas pelayanan kefarmasian di Puskesmas dikatakan "baik" apabila total skor $>86$, dikatakan "sedang" apabila total skor 65-85, dan dikatakan "kurang" apabila total skor $<65$.

\section{Hasil dan Pembahasan \\ Karakteristik Puskesmas Kabupaten Ponorogo}

Karakteristik Puskesmas di Kabupaten Ponorogo meliputi status dan akreditasi Puskesmas, serta penanggung jawab ruang farmasi sebagaimana ditampilkan pada Tabel 1 .

Tabel 1

Karakteristik Puskesmas Kabupaten Ponorogo

\begin{tabular}{llcc} 
& Karakteristik & Jumlah responden \\
$(\mathbf{n = 3 1})$ & Persentase (\%) \\
\hline \multirow{2}{*}{ Status } & Rawat inap & 19 & 61.3 \\
& Non rawat inap & 12 & 38.7 \\
\hline \multirow{5}{*}{ Akreditasi } & Dasar & 5 & 16.1 \\
& Madya & 22 & 71 \\
& Utama & 4 & 12.9 \\
& Paripurna & 0 & 0 \\
\multirow{3}{*}{ Penanggung jawab ruang farmasi } & 0 & 0 \\
& Tidak terakreditasi & 3 & 9.7 \\
& Apoteker & 24 & 77.4 \\
& Tenaga Teknis Kefarmasian (TTK) & 4 & 12.9 \\
\hline
\end{tabular}

Berdasarkan tabel di atas, diketahui bahwa karakteristik status Puskesmas dalam penelitian ini mayoritas adalah rawat inap $(61.3 \%)$. Perbedaan yang mendasar dari status suatu Puskesmas adalah ada tidaknya tambahan sumber daya guna penyelenggaraan pelayanan rawat inap sesuai kebutuhan.[8] Efendi dan Makhfudli menguraikan beberapa kriteria Puskesmas dapat berstatus rawat inap, yaitu: terletak kurang lebih $20 \mathrm{~km}$ dari rumah sakit, lokasi mudah dicapai dengan kendaraan bermotor, dipimpin oleh dokter dan memiliki tenaga yang memadai, jumlah kunjungan pasien minimal 100/hari, penduduk wilayah kerja Puskesmas dan tiga penduduk wilayah kerja Puskesmas sekelilingnya berjumlah minimal 20.000 jiwa, dan pemerintah bersedia menyediakan dana rutin yang memadai.[9] Pada karakteristik akreditasi, mayoritas adalah terakreditasi madya (71\%). Kementerian Kesehatan RI menjelaskan terkait standar akreditasi Puskesmas antara lain: Penyelenggaraan Pelayanan Puskesmas (PPP), Kepemimpinan dan Manajemen Puskesmas (KMP), Peningkatan Mutu dan Manajemen Risiko (PMMR), Upaya Kesehatan Masyarakat yang Berorientasi Sasaran (UKMBS), Kepemimpinan dan
Manajemen Upaya Kesehatan Masyarakat (KMUKM), Sasaran Kinerja UKM (SKUKM), Layanan Klinis yang Berorientasi Pasien (LKBP), Manajemen Penunjang Layanan Klinis (MPLK), serta Peningkatan Mutu Klinis dan Keselamatan Pasien (PMKP). Berdasarkan banyaknya pertimbangan dalam pengambilan keputusan status akreditasi, tidak diherankan beberapa Puskesmas dengan akreditasi utama dalam penelitian ini tidak memiliki apoteker, bahkan tenaga teknis kefarmasian (TTK) sekalipun.[8]

Pada karakteristik penanggung jawab ruang farmasi, diketahui mayoritas penanggung jawab Puskesmas Kabupaten Ponorogo adalah seorang TTK (77.4\%). Narasumber pihak Dinas Kesehatan Kabupaten Ponorogo menjelaskan terkait kendala dalam pemenuhan tenaga di Puskesmas antara lain pengangkatan tenaga BLUD, keterbatasan anggaran di Puskesmas, dan tidak mudahnya proses rekruitmen. Penempatan tenaga kesehatan termasuk tenaga kefarmasian di Puskesmas Kabupaten Ponorogo dilakukan berdasarkan pada perhitungan Analisis Beban Kerja (ABK) tanpa mengabaikan standar Puskesmas. 
Supardi dkk dalam penelitiannya menyatakan bahwa permasalahan dalam penempatan apoteker di Puskesmas adalah kurang prioritasnya kebutuhan apoteker dibandingkan tenaga kesehatan lain dan belum sesuainya usulan formasi terhadap perhitungan beban kerja serta kebutuhan riil organisasi sebagaimana diatur dalam peraturan perundangan yang menyebabkan Badan Kepegawaian Negara (BKN) menyetujui formasi terbatas. Keterbatasan formasi tersebut menghasilkan penempatan tenaga kesehatan yang tidak berdasarkan kompetensinya. [10]

\section{Gambaran Pelayanan Kefarmasian di Puskesmas Kabupaten Ponorogo}

Gambaran pelayanan kefarmasian di Puskesmas Kabupaten Ponorogo dapat diuraikan sebagai berikut: a. Penunjang pelayanan kefarmasian

Berdasarkan Tabel 2 diketahui bahwa 8 dari 10 aspek pada penunjang pelayanan kefarmasian telah dilakukan oleh seluruh Puskesmas di Kabupaten Ponorogo. Aspek tersebut meliputi tersedianya tulisan apotek/ruang farmasi, wadah yang sesuai untuk menyimpan obat, lemari terkunci untuk sediaan narkotika/psikotropika, kulkas untuk penyimpanan sediaan obat, buku acuan informasi obat, dan spanduk/poster yang memuat bahan informasi. Penyusunan obat secara alfabetis dan tempat serta peralatan peracikan dalam keadaan bersih sebelum digunakan juga sudah dilakukan. Aspek yang hanya dilaksanakan oleh beberapa Puskesmas pada penunjang pelayanan adalah tersedianya kartu/stok komputer (96.8\%) dan pemberian nomor urut pada resep masuk $(48.4 \%)$.

Tabel 2

Penunjang pelayanan kefarmasian di Puskesmas Kabupaten Ponorogo

\begin{tabular}{|c|c|c|c|}
\hline No & Kegiatan & $\begin{array}{c}\text { Jumlah responden } \\
(\mathbf{n}=\mathbf{3 1})\end{array}$ & $\begin{array}{l}\text { Persentase } \\
\%\end{array}$ \\
\hline \multirow[t]{3}{*}{1} & $\begin{array}{l}\text { Ada tulisan "apotek" atau "ruang farmasi" pada ruang pelayanan kefarmasian di } \\
\text { Puskesmas }\end{array}$ & & \\
\hline & Ya & 31 & 100 \\
\hline & Tidak & 0 & 0 \\
\hline \multirow[t]{3}{*}{2} & Obat disimpan di dalam wadah asli atau wadah yang sesuai & & \\
\hline & Ya & 31 & 100 \\
\hline & Tidak & 0 & 0 \\
\hline \multirow[t]{3}{*}{3} & Penyusunan obat disusun secara alfabetis & & \\
\hline & Ya & 31 & 100 \\
\hline & Tidak & 0 & 0 \\
\hline \multirow[t]{3}{*}{4} & 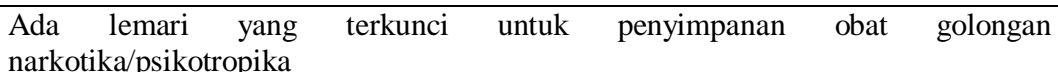 & & \\
\hline & Ya & 31 & 100 \\
\hline & Tidak & 0 & 0 \\
\hline \multirow[t]{3}{*}{5} & $\begin{array}{l}\text { Ada kulkas untuk penyimpanan obat (seperti supositoria, vaksin) yang } \\
\text { membutuhkan suhu dingin }\end{array}$ & & \\
\hline & Ya & 31 & 100 \\
\hline & Tidak & 0 & 0 \\
\hline \multirow[t]{3}{*}{6} & $\begin{array}{l}\text { Ada kartu/stok komputer untuk mencatat penambahan dan pengurangan setiap } \\
\text { jenis obat }\end{array}$ & & \\
\hline & Ya & 30 & 96.8 \\
\hline & Tidak & 1 & 3.2 \\
\hline \multirow[t]{3}{*}{7} & Tempat dan peralatan peracikan dalam keadaan bersih sebelum bekerja & & \\
\hline & Ya & 31 & 100 \\
\hline & Tidak & 0 & 0 \\
\hline \multirow[t]{3}{*}{8} & Resep pasien yang masuk diberi nomor urut & & \\
\hline & Ya & 15 & 48.4 \\
\hline & Tidak & 16 & 51.6 \\
\hline \multirow[t]{3}{*}{9} & $\begin{array}{l}\text { Ada buku Informasi Spesialite Obat Indonesia (ISO) atau buku lain sebagai acuan } \\
\text { untuk infotmasi obat kepada pasien }\end{array}$ & & \\
\hline & Ya & 31 & 100 \\
\hline & Tidak & 0 & 0 \\
\hline \multirow[t]{3}{*}{10} & $\begin{array}{l}\text { Tersedia bahan informasi berupa spanduk, poster, booklet, leaflet atau lainnya } \\
\text { Ya }\end{array}$ & & \\
\hline & Tidak & 31 & 100 \\
\hline & & 0 & 0 \\
\hline
\end{tabular}

Puskesmas yang tidak lagi menerapkan kartu stok dalam pencatatan keluar masuk obat dilatarbelakangi oleh keterbatasan SDM. Diketahui pelayanan kefarmasian di
Puskesmas tersebut hanya dilaksanakan oleh 3 tenaga kefarmasian (1 apoteker dan 2 TTK) dengan jumlah kunjungan tiap bulannya mencapai 3.000 pasien. 
Pelaksana pelayanan kefarmasian di Puskesmas yang tidak memberikan nomor urut pada resep masuk, hanya menumpuk resep berdasarkan status pasien (BPJS atau umum). Penomoran pada resep dirasa penting untuk meminimalisir kesalahan pemberian obat pada pasien dengan nama yang sama tetapi indikasi berbeda. Namun hal tersebut tidak berlaku di Puskesmas dengan jumlah pengunjung kurang dari 10 pasien setiap harinya. Petugas ruang farmasi beranggapan bahwa tanpa penomoran pada resep tidak akan mengubah antrean pengambilan obat ataupun kesalahan pemberian obat, karena jarak antar pasien dinilai cukup lama.

b. Pelayanan kefarmasian

Pelaksana pelayanan kefarmasian di Puskesmas Kabupaten Ponorogo dilakukan oleh apoteker, TTK atau tenaga lain. Indikator pelayanan kefarmasian dalam penelitian ini terbagi atas 3 aspek besar yang meliputi: pemeriksaan resep, dispensing, dan penyerahan obat. Pada aspek pemeriksaan resep, kegiatan terbagi lagi menjadi pemeriksaan kelengkapan resep, pemeriksaan keabsahan resep, pertimbangan klinik, dan pemeriksaan obat.

Berdasarkan Tabel 3 diketahui bahwa pada aspek pemeriksaan resep, pelaksana pelayanan kefarmasian oleh apoteker di 3 Puskesmas telah melakukan kegiatan pemeriksaan kelengkapan resep, rangkaian pemeriksaan keabsahan resep, pemeriksaan obat, dan pertimbangan klinik terkait dosis obat, medikasi rangkap, serta kontraindikasi. Kegiatan yang belum dilakukan oleh seluruh pelaksana pelayanan seorang apoteker adalah pertimbangan klinik terkait interaksi obat dan reaksi alergi.

Tabel 3

Pemeriksaan resep pada pelayanan kefarmasian

\begin{tabular}{clcc}
\hline No & Kegiatan & Jumlah responden $(\mathbf{n}=\mathbf{3 1})$ & Persentase $(\boldsymbol{\%})$ \\
\hline 1 & Pemeriksaan kelengkapan resep & 3 & 9.7 \\
& Apoteker & 19 & 61.3 \\
& TTK & 9 & 29 \\
& Tenaga lain & 0 & 0 \\
& Tidak dilakukan & 0 & \\
\hline
\end{tabular}

2 Pemeriksaan keabsahan resep

a. Dokter penulis resep: tanggal, nama, nomor NIP/SIP, alamat

Puskesmas, tanda tangan

Apoteker

TTK

Tenaga lain

Tidak dilakukan

b. Penderita: nama, alamat, umur, jenis kelamin, dan berat badan

Apoteker

TTK

Tenaga lain

Tidak dilakukan

$\begin{array}{ll}19 & 29 \\ 9 & \end{array}$

c. Obat: nama obat, bentuk sediaan, dosis, jumlah, cara pemakaian Apoteker

TTK

$\begin{array}{ll}3 & 9.7\end{array}$

Tenaga lain Tidak dilakukan

3 Pertimbangan klinik yang dilakukan

a. Dosis obat

Apoteker

TTK

Tenaga lain

Tidak dilakukan

45.2

Medikasi rangkap

19.4

Apoteker

TTK

Tenaga lain

c. Kontraindikasi

Apoteker

TTK

$\begin{array}{cc}3 & 9.7 \\ 1 & 3.2 \\ 0 & 0 \\ 27 & 87.1\end{array}$


d. Interaksi obat $\begin{array}{lcc}\text { Apoteker } & 2 & 6.5\end{array}$

$\begin{array}{lrr}\text { TTK } & 2 & 6.5\end{array}$

Tenaga lain $\quad 0 \quad 0$

$\begin{array}{lll}\text { Tidak dilakukan } & 27 & 87\end{array}$

$\begin{array}{lrr}\text { e. Reaksi alergi } & 2 & 6.5 \\ \text { Apoteker } & 2 & 3.2\end{array}$

$\begin{array}{lrr}\text { TTK } & 1 & 3.2\end{array}$

Tenaga lain $\quad 0 \quad 0$

Tidak dilakukan $\quad 28 \quad 90.3$

4 Pemeriksaan obat

a. Memeriksa ketersediaan obat di ruang farmasi

Apoteker

TTK

Tenaga lain

Tidak dilakukan

$\begin{array}{cc}3 & 9.7 \\ 19 & 61.3 \\ 9 & 29 \\ 0 & 0 \\ & \\ 3 & 9.7 \\ 19 & 61.3 \\ 9 & 29 \\ 0 & 0 \\ 3 & \\ 19 & 9.7 \\ 9 & 61.3 \\ 0 & 29 \\ \end{array}$

b. Memeriksa kualitas fisik obat

Apoteker

TTK

Tenaga lain

Tidak dilakukan

c. Memeriksa tanggal kedaluwarsa

Apoteker

TTK

Tenaga lain

Tidak dilakukan

dilakukan bukan oleh apoteker. Pertimbangan klinik pada pelayanan kefarmasian di Puskesmas Kabupaten Ponorogo yang dilakukan bukan oleh apoteker umumnya dilaksanakan di ruang Balai Pengobatan (BP).

Aspek selanjutnya pada indikator pelayanan adalah dispensing. Pelaksana pelayanan kefarmasian baik seorang apoteker, TTK, maupun tenaga lain telah melakukan kegiatan serta pemeriksaan hasil dispensing di tiap unitnya. Berdasarkan Tabel 4 juga disebutkan bahwa mayoritas etiket di Puskesmas Kabupaten Ponorogo telah berisi informasi sesuai resep dokter dengan penulisan yang jelas (93.5\%), tetapi penggunaan etiket sesuai jenis obat hanya terlaksana di $80.6 \%$ Puskesmas. Beberapa Puskesmas tersebut menggunakan etiket untuk penggunaan obat dalam, sedangkan untuk obat luar hanya ditulis menggunakan spidol permanen pada kemasan sediaan.

Tabel 4

Dispensing pada pelayanan kefarmasian

\begin{tabular}{|c|c|c|c|}
\hline No & 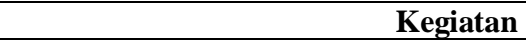 & Jumlah responden $(n=31)$ & Persentase (\%) \\
\hline \multirow{5}{*}{1} & Pelaksana dispensing & & \\
\hline & Apoteker & 3 & 9.7 \\
\hline & TTK & 19 & 61.3 \\
\hline & Tenaga lain & 9 & 29 \\
\hline & Tidak dilakukan & 0 & 0 \\
\hline \multirow[t]{5}{*}{2} & Pemeriksa hasil dispensing & & \\
\hline & Apoteker & 3 & 9.7 \\
\hline & TTK & 19 & 61.3 \\
\hline & Tenaga lain & 9 & 29 \\
\hline & Tidak dilakukan & 0 & 0 \\
\hline
\end{tabular}




\begin{tabular}{llcc}
\hline & Ya & 29 & 93.5 \\
& Tidak & 2 & 6.5 \\
\hline 4 & Tulisan di etiket jelas dan mudah terbaca & & \\
& Ya & 29 & 93.5 \\
& Tidak & 2 & 6.5 \\
\hline 5 & Etiket disesuaikan dengan jenis obat (etiket warna putih untuk obat & \\
& dalam dan etiket warna biru untuk obat luar) & & 80.6 \\
& Ya & 25 & 19.4 \\
& Tidak & 6 & \\
\hline
\end{tabular}

Aspek terakhir pada indikator pelayanan adalah penyerahan obat. Hasil dalam penelitian ini menunjukkan bahwa pelaksana pelayanan kefarmasian oleh seorang apoteker telah melakukan kegiatan penyerahan obat yang disertai rangkaian informasi kepada pasien terkait dosis obat, frekuensi pemakaian, lama pengobatan, cara pemakaian, efek samping, serta cara penyimpanan sesuai aturan, dan konseling untuk pasien yang membutuhkan. Kegiatan yang belum dilakukan oleh seluruh pelaksana pelayanan kefarmasian seorang apoteker adalah pemberian informasi terkait kontraindikasi dan aktivitas home care.

Pada Standar Pelayanan Kefarmasian di Puskesmas menyebutkan beberapa pelayanan farmasi klinik yang harus dilakukan seorang apoteker, diantaranya adalah pengkajian dan pelayanan resep, Pelayanan Informasi Obat (PIO), konseling, visite pasien pada puskesmas rawat inap, Monitoring Efek Samping Obat (MESO), Pemantauan Terapi Obat (PTO), dan evaluasi penggunaan obat.[3] Namun, pada daftar tilik yang digunakan dalam penelitian ini memang tidak disebutkan terkait visite pasien, MESO, PTO, dan evaluasi penggunaan obat.

\section{Tabel 5}

Penyerahan obat pada pelayanan kefarmasian

\begin{tabular}{ccccc}
\hline No & & Kegiatan & Jumlah responden $(\mathbf{n}=\mathbf{3 1})$ & Persentase $(\%)$ \\
\hline 1 & Penyerah obat & 3 & 9.7 \\
& Apoteker & & 19 & 61.3 \\
& TTK & 9 & 29 \\
& Tenaga lain & Tidak dilakukan & 0 & 0 \\
\hline
\end{tabular}

2 Informasi obat yang diberikan kepada pasien
a. Dosis obat
Apoteker
3
TTK
Tenaga lain
Tidak dilakukan
b. Frekuensi pemakaian obat Apoteker
TTK
Tenaga lain
Tidak dilakukan
ama pengobatan
Apoteker
TTK
Tenaga lain
Tidak dilakukan

Kegiatan yang telah dilakukan pelaksana pelayanan kefarmasian seorang TTK maupun tenaga lain pada aspek ini adalah telah dilakukannya penyerahan obat yang disertai informasi kepada pasien terkait dosis obat dan cara pemakaian. Kegiatan yang belum dilakukan adalah konseling, home care, dan pemberian informasi terkait lama pengobatan, efek samping, kontraindikasi, serta cara penyimpanan obat. Namun, untuk pemberian informasi terkait lama pengobatan, pelaksana pelayanan kefarmasian seorang tenaga lain telah melakukannya sebagaimana ditampilkan pada Tabel 5 .

Hasil penelitian menunjukkan bahwa pelayanan kefarmasian masih belum berjalan secara maksimal di Puskesmas Kabupaten Ponorogo. Hal tersebut disebabkan pelaksana pelayanan kefarmasian mayoritas adalah seorang TTK. Peraturan Menteri Kesehatan RI Nomor 74 Tahun 2016 menjelaskan bahwa pelaksanaan pelayanan kefarmasian yang dilakukan bukan oleh seorang apoteker hanya terbatas pada pengelolaan sediaan farmasi serta bahan medis habis pakai dan pelayanan resep dimana meliputi peracikan serta penyerahan obat, dan pemberian informasi.[3] 


\begin{tabular}{|c|c|c|c|}
\hline \multicolumn{2}{|r|}{ TTK } & \multirow{2}{*}{$\begin{array}{c}19 \\
9\end{array}$} & 61,3 \\
\hline & Tenaga lain & & 29 \\
\hline & Tidak dilakukan & 0 & 0 \\
\hline \multicolumn{4}{|c|}{ e. Efek samping } \\
\hline & Apoteker & 3 & 9.6 \\
\hline & TTK & 14 & 45.2 \\
\hline & Tenaga lain & 6 & 19.4 \\
\hline & Tidak dilakukan & 8 & 25.8 \\
\hline \multicolumn{4}{|c|}{ f. Kontraindikasi } \\
\hline & Apoteker & 1 & 3.2 \\
\hline & TTK & 1 & 3.2 \\
\hline & Tenaga lain & 0 & 0 \\
\hline & Tidak dilakukan & 29 & 93.6 \\
\hline \multicolumn{4}{|c|}{ g. Cara penyimpanan obat sesuai aturan } \\
\hline & Apoteker & 3 & 9.7 \\
\hline & TTK & 13 & 41.9 \\
\hline & Tenaga lain & 4 & 12.9 \\
\hline & Tidak dilakukan & 11 & 35.5 \\
\hline \multicolumn{4}{|c|}{ Konseling kepada pasien } \\
\hline & Apoteker & 3 & 9.7 \\
\hline & TTK & 1 & 3.2 \\
\hline & Tenaga lain & 0 & 0 \\
\hline & Tidak dilakukan & 27 & 87.1 \\
\hline \multicolumn{4}{|c|}{ Home care pada pasien penyakit kronis yang terdokumentasi } \\
\hline & Apoteker & 0 & 0 \\
\hline & TTK & 0 & 0 \\
\hline & Tenaga lain & 0 & 0 \\
\hline & Tidak dilakukan & 31 & 100 \\
\hline
\end{tabular}

c. Pengendalian mutu pelayanan kefarmasian

Indikator terakhir pada pelayanan kefarmasian adalah pengendalian mutu pelayanan kefarmasian. Berdasarkan Tabel 6 dapat diketahui bahwa di seluruh Puskesmas Kabupaten Ponorogo telah menyediakan standar prosedur tetap, buku pedoman pengobatan serta pedoman PIO, Laporan Pemakaian dan Lembar Permintaan Obat (LPLPO), laporan obat kedaluwarsa, dan kotak saran maupun kotak survei. Dispensing dan pelatihan untuk tenaga di Puskesmas juga sudah dilakukan. Kegiatan yang belum dilaksanakan oleh seluruh Puskesmas adalah pendidikan berkelanjutan untuk tenaga farmasi $(\mathrm{n}=8 ; 25.8 \%)$ serta ketersediaan laporan obat rusak $(\mathrm{n}=20 ; 54.5 \%)$, laporan kesalahan pemberian obat $(\mathrm{n}=13 ; 41.9 \%)$, laporan psikotropika $(\mathrm{n}=19 ; 61.3 \%)$, dan laporan obat hilang $(n=3 ; 9.7 \%)$. Laporan narkotika justru tidak ditemukan di seluruh Puskesmas.

Pendidikan berkelanjutan merupakan penawaran dari pemerintah untuk tenaga kefarmasian yang belum menempuh program vokasi (D3). Pendidikan tersebut ditujukan untuk mewacanakan tenaga kefarmasian di Puskesmas minimal adalah D3 di tahun 2020. Pendidikan berkelanjutan juga salah satu upaya yang dilakukan dalam mengembangkan profesional berkelanjutan, sebagaimana disebutkan dalam Peraturan Menteri Kesehatan RI Nomor 74 Tahun 2016.

Beberapa laporan yang belum tersedia di seluruh Puskesmas terkait obat rusak, kesalahan pemberian obat, psikotropika dan obat hilang disebabkan kurang relevannya antara daftar tilik dengan kebutuhan Puskesmas saat ini. Diketahui bahwa Dinas Kesehatan Kabupaten Ponorogo hanya meminta pelaporan rutin terkait LPLPO (Laporan pemakaian dan Lembar Penerimaan Obat), laporan obat beli, laporan POR (Pemakaian Obat Rasional), laporan evaluasi kesesuaian item obat dengan Fornas, dan 10 indikator kesesuaian obat. 
Tabel 6.

Pengendalian mutu pelayanan kefarmasian di Puskesmas Kabupaten Ponorogo

\begin{tabular}{|c|c|c|c|}
\hline No & Kegiatan & $\begin{array}{l}\text { Jumlah responden } \\
(\mathbf{n}=\mathbf{3 1})\end{array}$ & Persentase $(\%)$ \\
\hline \multirow[t]{20}{*}{1} & $\begin{array}{l}\text { Dalam rangka peningkatan mutu pelayanan kefarmasian di Puskesmas, } \\
\text { tersedia/dilakukan: }\end{array}$ & & \\
\hline & a. Prosedur tetap pelayanan kefarmasian & & \\
\hline & Ya & 31 & 100 \\
\hline & Tidak & 0 & 0 \\
\hline & b. Dispensing & & \\
\hline & Ya & 31 & 100 \\
\hline & Tidak & 0 & 0 \\
\hline & c. Buku pedoman pengobatan di Puskesmas & & \\
\hline & Ya & 31 & 100 \\
\hline & Tidak & 0 & 0 \\
\hline & d. Buku pedoman PIO & & \\
\hline & Ya & 31 & 100 \\
\hline & Tidak & 0 & 0 \\
\hline & e. Pendidikan berkelanjutan untuk tenaga kefarmasian di Puskesmas & & \\
\hline & Ya & & \\
\hline & Tidak & 8 & 25.8 \\
\hline & & 23 & 74.2 \\
\hline & f. Pelatihan-pelatihan untuk tenaga di Puskesmas & & \\
\hline & Ya & 31 & 100 \\
\hline & Tidak & 0 & 0 \\
\hline \multirow[t]{22}{*}{2} & Evaluasi mutu pelayanan & & \\
\hline & a. Laporan Pemakaian dan Lembar Permintaan Obat (LPLPO) & & \\
\hline & Ya & 31 & 100 \\
\hline & Tidak & 0 & 0 \\
\hline & b. Laporan obat rusak & & \\
\hline & Ya & 20 & 64.5 \\
\hline & Tidak & 11 & 35.5 \\
\hline & c. Laporan obat kedaluwarsa & & \\
\hline & Ya & 31 & 100 \\
\hline & Tidak & 0 & 0 \\
\hline & d. Laporan kesalahan pemberian obat & & \\
\hline & Ya & 13 & 41.9 \\
\hline & Tidak & 18 & 58.1 \\
\hline & e. Laporan narkotika & & \\
\hline & Ya & 0 & 0 \\
\hline & Tidak & 31 & 100 \\
\hline & f. Laporan psikotropika & & \\
\hline & Ya & 19 & 61.3 \\
\hline & Tidak & 12 & 38.7 \\
\hline & g. Laporan obat hilang & & \\
\hline & Ya & 3 & 9.7 \\
\hline & Tidak & 28 & 90.3 \\
\hline \multirow[t]{6}{*}{3} & $\begin{array}{l}\text { Melakukan evaluasi terhadap tingkat kepuasan konsumen } \\
\text { a. Survei }\end{array}$ & & \\
\hline & Ya & 31 & 100 \\
\hline & Tidak & 0 & 0 \\
\hline & b. Kotak saran & & \\
\hline & Ya & 31 & 100 \\
\hline & Tidak & 0 & 0 \\
\hline
\end{tabular}

Aspek yang juga disebutkan berperan dalam meningkatkan mutu pelayanan adalah pelaksanaan dispensing. Dispensing merupakan kegiatan penyerahan obat yang dilanjutkan dengan Pemberian Informasi Obat (PIO). Kegiatan pelayanan tersebut dimulai dari tahap menyiapkan obat, memberikan etiket, dan menyerahkan sediaan farmasi dengan informasi memadai yang disertai pendokumentasian. [3] Pendokumentasian dilakukan dengan cara mengisi format dimana sekurang-kurangnya memuat identitas pasien, nama obat, dosis obat, dan lama pengobatan.

Pada kegiatan evaluasi tingkat kepuasan konsumen di Puskesmas Kabupaten Ponorogo, penilaian dapat dilakukan dengan kotak survei ataupun kotak saran. Pengisian kotak kepuasan di masing-masing Puskesmas cukup beragam. Terdapat Puskesmas yang menggunakan emotikon puas/tidak puas untuk seluruh ruangan pelayanan, terdapat pula 
Puskesmas yang memberikan kartu dengan warna berbeda di tiap ruangan pelayanan. Umumnya rekapitulasi dari kotak kepuasan dilakukan setiap jam pulang kerja oleh petugas.

Evaluasi terhadap kepuasan konsumen tidak hanya dari kotak survei maupun kotak saran, beberapa Puskesmas di Kabupaten Ponorogo juga melakukan evaluasi dengan cara menyebarkan kuesioner. Berbeda dengan kotak survei dan kotak saran, dimana penilaian menggunakan kuesioner kepuasan dilakukan setiap 3 bulan sekali.

\section{Kualitas Pelayanan Kefarmasian di Puskesmas Kabupaten Ponorogo}

Total skor dalam pengisian daftar tilik kemudian dikonversi terhadap kualitas pelayanan kefarmasian, sehingga diperoleh kualitas pelayanan kefarmasian di Puskesmas Kabupaten Ponorogo mayoritas adalah "kurang" $(n=20 ; 64.5 \%)$ sebagaimana dapat dilihat pada Tabel 7.

Tabel 7

Kualitas pelayanan kefarmasian di Puskesmas Kabupaten Ponorogo

\begin{tabular}{|c|c|c|c|c|c|}
\hline No. & Unit Kerja & PJ ruang farmasi & Total skor & Kualitas Pelayanan & Persentase (\%) \\
\hline 1 & P 13 & Apoteker & 96 & \multirow{3}{*}{ Baik } & \multirow{3}{*}{9.7} \\
\hline 2 & P 9 & Apoteker & 92 & & \\
\hline 3 & P 12 & Apoteker & 92 & & \\
\hline 4 & P 25 & TTK & 70 & \multirow{8}{*}{ Sedang } & \multirow{8}{*}{25.8} \\
\hline 5 & P 8 & TTK & 69 & & \\
\hline 6 & P 5 & TTK & 68 & & \\
\hline 7 & P22 & TTK & 68 & & \\
\hline 8 & P 14 & TTK & 65 & & \\
\hline 9 & P 7 & TTK & 65 & & \\
\hline 10 & P 15 & TTK & 65 & & \\
\hline 11 & P 24 & TTK & 65 & & \\
\hline 12 & P 1 & TTK & 63 & \multirow{20}{*}{ Kurang } & \multirow{20}{*}{64.5} \\
\hline 13 & P 4 & TTK & 63 & & \\
\hline 14 & P 16 & TTK & 63 & & \\
\hline 15 & P 21 & TTK & 63 & & \\
\hline 16 & P 10 & TTK & 62 & & \\
\hline 17 & P 20 & TTK & 62 & & \\
\hline 18 & P 23 & TTK & 62 & & \\
\hline 19 & P 26 & TTK & 62 & & \\
\hline 20 & P 28 & TTK & 62 & & \\
\hline 21 & P 11 & TTK & 57 & & \\
\hline 22 & P 29 & TTK & 57 & & \\
\hline 23 & P 2 & TTK & 53 & & \\
\hline 24 & P 17 & TTK & 51 & & \\
\hline 25 & P 18 & TTK & 49 & & \\
\hline 26 & P 3 & TTK & 47 & & \\
\hline 27 & P 27 & TTK & 47 & & \\
\hline 28 & P 6 & Tenaga kesehatan lain & 46 & & \\
\hline 29 & P 19 & Tenaga kesehatan lain & 46 & & \\
\hline 30 & P 31 & Tenaga kesehatan lain & 38 & & \\
\hline 31 & P 30 & Tenaga kesehatan lain & 36 & & \\
\hline
\end{tabular}

Hasil penelitian menunjukkan bahwa dari 31 Puskesmas Kabupaten Ponorogo, sebesar 9.7\% kualitas pelayanan kefarmasian "baik" didapatkan oleh penanggung jawab seorang apoteker. Hal ini disebabkan penanggung jawab sekaligus pelaksana pelayanan kefarmasian tersebut dilakukan oleh apoteker, dimana dalam daftar tilik akan mendapatkan skor 2 pada setiap poinnya. Kualitas pelayanan kefarmasian "sedang" dan "baik" berturut-turut sebesar $25.8 \%$ dan $9.7 \%$. Hasil ini sesuai dengan penelitian Hanggara dkk [5] yang menggunakan daftar tilik serupa, dimana 37 dari 39 puskesmas di Kabupaten Banyumas memiliki kualitas pelayanan kefarmasian "kurang".

Tingginya kualitas pelayanan kefarmasian "kurang" di Puskesmas Kabupaten Ponorogo dipengaruhi oleh skor pada indikator pelayanan kefarmasian. Pelaksana pelayanan kefarmasian umumnya dilakukan oleh seorang tenaga kesehatan lain, sehingga skor yang didapat adalah 0 . Diketahui tenaga kefarmasian di Puskesmas Kabupaten Ponorogo dari hasil penelitian diketahui hanya sejumlah 34 orang ( 3 apoteker dan 31 TTK). Banyaknya beban kerja yang dilimpahkan kepada tenaga kefarmasian di Puskesmas mengharuskan tenaga kefarmasian mendelegasikan beberapa tugas kepada tenaga lain (tenaga kesehatan maupun non tenaga kesehatan). Pendelegasian tersebut mayoritas dilakukan untuk pelaksanaan pelayanan di ruang farmasi. Supardi dkk (2012) menyebutkan belum berjalannya pelayanan kefarmasian di Puskesmas dengan baik 
dikarenakan ketersediaan dan jumlah apoteker tidak sesuai terhadap beban kerja.

Total skor maksimum yang mungkin didapatkan Puskesmas dengan penanggung jawab ruang farmasi sekaligus pelaksana pelayanan kefarmasian seorang apoteker, TTK, dan tenaga lain berturut-turut adalah 106, 81, dan 56. Sehingga, potensi kualitas pelayanan kefarmasian "baik" hanya diperuntukkan pada Puskesmas dengan penanggung jawab ruang farmasi sekaligus pelaksana pelayanan kefarmasian seorang apoteker. Daftar tilik yang digunakan sebagai acuan penilaian kualitas pelayanan kefarmasian di Puskesmas dalam penelitian ini merupakan pedoman yang mengharapkan seluruh pelayanan dilakukan oleh seorang apoteker, dimana ketersediaan apoteker atau TTK sangat berpengaruh pada total skor.

\section{Kesimpulan}

Kesimpulan yang dapat diambil pada penelitian ini adalah:

a. Karakteristik Puskesmas Kabupaten Ponorogo didominasi oleh Puskesmas dengan status rawat inap, terakreditasi madya, dan penanggung jawab ruang farmasi adalah seorang TTK.

b. Gambaran pelayanan kefarmasian di Puskesmas Kabupaten Ponorogo umumnya telah terpenuhi pada indikator penunjang pelayanan dan mutu pelayanan kefarmasian. Tetapi, untuk indikator pelayanan kefarmasian pada kegiatan pertimbangan klinik, konseling, dan home care masih belum sepenuhnya dilakukan.

c. Kualitas pelayanan kefarmasian di Puskesmas Kabupaten Ponorogo mayoritas adalah "kurang" yaitu sebanyak 20 unit kerja, sedangkan untuk kualitas pelayanan kefarmasian "sedang" dan "baik" berturut-turut sebanyak 8 unit kerja dan 3 unit kerja.

\section{Ucapan Terima Kasih}

Penulis menyampaikan terima kasih kepada Dinas Kesehatan Kabupaten Ponorogo dan responden penelitian di seluruh Puskesmas Kabupaten Ponorogo.

\section{Referensi}

[1] Pemerintah Republik Indonesia. 2009. Undang-Undang Republik Indonesia Nomor 36 Tahun 2009 tentang Kesehatan. Jakarta: Pemerintah RI.

[2] Pemerintah Republik Indonesia. 2016. Peraturan Pemerintah Republik Indonesia Nomor 47 Tahun 20016 tentang Fasilitas Pelayanan Kesehatan. Jakarta: Pemerintah RI.

[3] Kementerian Kesehatan Republik Indonesia. 2016. Peraturan Menteri Republik Indonesia Nomor 44 Tahun 2016 tentang Pedoman Manajemen Puskesmas. Jakarta: Kementerian Kesehatan RI.

[4] Herman, M.J., S. Supardi, dan Y. Yuniar. 2013. Hubungan ketersediaan tenaga kefarmasian dengan karakteristik puskesmas dan praktik kefarmasian di puskesmas. Buletim Penelitian Sistem Kesehatan. 16 (1): 88-98.

[5] Hanggara, S.R., N. C. Gibran, A. M. Kusuma, dan G. F. Galistiani. 2017. Pengaruh keberadaan apoteker terhadap mutu pelayanan kefarmasian di puskesmas wilayah kabupaten banyumas. Jurnal Kefarmasian Indonesia. 7 (1): 67-76.

[6] Departemen Kesehatan Republik Indonesia. 2006. Pedoman Pelayanan Kefarmasian di Puskesmas. Jakarta: Departemen Kesehatan RI.

[7] Departemen Kesehatan Republik Indonesia. 2008. Modul TOT Pedoman Pelayanan Kefarmasian di Puskesmas. Jakarta: Departemen Kesehatan RI.

[8] Kementerian Kesehatan Republik Indonesia. 2014. Peraturan Menteri Republik Indonesia Nomor 75 Tahun 2014 tentang Pusat Kesehatan Masyarakat. Jakarta: Kementerian Kesehatan RI

[9] Efendi, F., dan Makhfudli. 2009. Keperawatan Kesehatan Komunitas: Teori dan Praktik dalam Keperawatan. Jakarta: Salemba Medika.

[10] Supardi, S., Raharni, A. L. Susyanti, dan M. J. Herman. 2012. Evaluasi peran apoteker berdasarkan pedoman pelayanan kefarmasian di puskesmas. Media Litbang Kesehatan. 23(4): 190-198. 